\title{
The Importance of Auditory Discrimination in the Acquisition of Mental Lexicon and Reading Automation in Arabic-Speaking Students in Kenitra (Morocco)
}

\author{
Chaouki Sadoussi', Ahmed Ahami1, Abdechahid Loukili1,2, Khaoula Mammad1, \\ Abdessamad Mrabet1 \\ ${ }^{1}$ Unit of Clinic and Cognitive Neurosciences and Health, Laboratory of Biology and Health, Department of Biology, Faculty of \\ Science, University Ibn Tofail, Kenitra, Morocco \\ ${ }^{2}$ Regional Center for Teaching and Training Professions, Rabat-Sale-Kenitra, Morocco \\ Email:khaoula.mammad@gmail.com
}

How to cite this paper: Sadoussi, C., Ahami, A., Loukili, A., Mammad, K. and Mrabet, A. (2018) The Importance of Auditory Discrimination in the Acquisition of Mental Lexicon and Reading Automation in Arabic-Speaking Students in Kenitra (Morocco). Open Journal of Medical Psychology, 7, 27-33.

https://doi.org/10.4236/ojmp.2018.73003

Received: May 21, 2018

Accepted: July 2, 2018

Published: July 5, 2018

Copyright () 2018 by authors and Scientific Research Publishing Inc. This work is licensed under the Creative Commons Attribution International License (CC BY 4.0).

http://creativecommons.org/licenses/by/4.0/

\begin{abstract}
Auditory discrimination is the ability to discriminate between words and sounds. Auditory discrimination can affect reading, spelling and writing. Several studies examined the correlation between auditory discrimination and reading performance. The aim of this study is to demonstrate the importance of auditory discrimination in the acquisition of mental lexicon and consequently the automation of reading in a sample of 101 students in their fourth year of primary education coming from four different schools in Kenitra (Morocco). The results analysis shows that reading scores correlated significantly with the auditory discrimination scores $(r=0.30, p<0.01)$. This proves that the inability to discriminate words causes a disability to store them in the mental lexicon, which makes it difficult to identify these words at a later encounter. This conclusion is supported by the significant correlation between reading and auditory and visual lexical decision tasks. In this study we were able to emphasize the importance of having good acoustic discrimination capacities for language development. Students who were successful at the auditory discrimination task are more successful at reading. A remediation program based on improving auditory discrimination capacities using the language assessment battery LABBEL could see reading performance improvement in these students.
\end{abstract}

\section{Keywords}

Auditory Discrimination, Reading, LABBEL, Mental Lexicon, Reading Acquisition 


\section{Introduction}

Reading is a complex and flexible activity that involves the cognitive arsenal [1]. Several studies have demonstrated the importance of phonological awareness at the beginning of the acquisition of reading [2]. Accessing writing in an alphabetic system is a complex process that requires the ability to manipulate the phonological components of language. In fact, the initial stages of learning to read are characterized by the establishment of the connection between graphemic representations and corresponding phonological representations [3] [4]. According to Gombert $(1990,2004)$, phonological awareness is the ability to identify the phonological components of linguistic units and manipulate them deliberately [5] [6]. To recognize a word is not to find that word somewhere in memory, but to recover a certain state of activation of the units which, in the cognitive system, are concerned with the processing of lexical information [7]. Very often, learners who cannot recognize the sound forms of words are confronted with orthographic transcription problems [8]. Auditory discrimination is phoneme differentiation and phoneme identification [9]. Our ability to discriminate auditory information is directly linked to our learning capacity. A few authors by analyzing auditory discrimination in children with phonological disorder, have suggested that these children have phonemic discrimination difficulties [10] [11]. Auditory discrimination can affect reading, spelling and writing, during learning and as word recognition becomes automated. This automation is a mobilization of attentional resources in the service of understanding [8]. Disordered auditory abilities make it impossible to correctly use speech phonemes [12]. The aim of this study is to demonstrate the importance of auditory discrimination in the acquisition of mental lexicon and consequently the automation of reading.

\section{Materials and Methods}

The study involved a sample of 101 students in their fourth year of primary education coming from four different schools in Kenitra (Morocco) aged 9 to 14 years old (mean age $=10.29 \pm 1.05)$. Our sample is composed of $60 \%$ boys $(n=$ $61)$ and $40 \%$ girls $(n=40)$ (Figure 1$)$.

The choice of the fourth year of primary education for this study was based on the assumption that at this level, the students have sufficient skills to perform the different language tasks of the used protocol.

In case of the diagnosis of learning disabilities in these students, who still have two years before their crucial transition to high school, they could benefit from a remediation program.

The participants were randomly selected from four schools. Students with mental disorders were excluded from the research. This study was held on January 2016. For ethical considerations, this study was carried out only after the agreement of the subjects and the delegation of the ministry of education in Kenitra. 


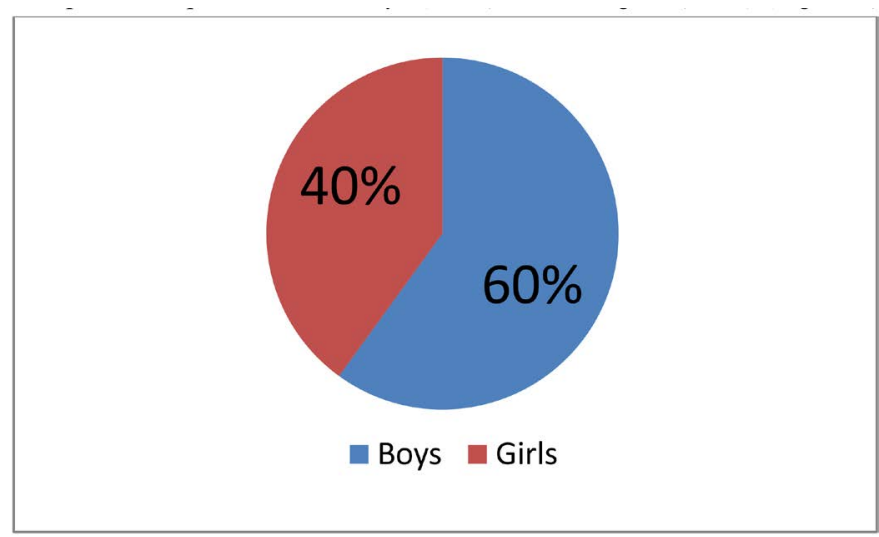

Figure 1. Students distribution according to gender.

\section{Language Assessment Battery LABBEL}

In this study we opted for the use of four activities from the arabic version of the language assessment battery LABBEL [13]. This software (LABBEL) was conceived by two neurolinguistic researchers who have used their knowledge of neurolinguistics, psycholinguistics, morphology, phonology and Arabic syntax to develop a battery of tests that takes into account the linguistic characteristics of the Arabic language. The students took the following four tests of the LABBEL battery [14], each test contained 10 items. The score for each test was obtained by subtracting the number of errors from the number of items presented (10 items), thus the score varies between 0 and 10 .

- Auditory lexical decision: After a presentation of words and non-words in auditory input, the subject must determine if the stimulus is indeed an Arabic language word or not.

- Visual lexical decision: After a presentation of the written words and non-words, the subject must determine if the stimulus is indeed a word of Arabic language or not.

- Auditory discrimination: The subject must determine whether the word pair presented is identical or different.

- Complex words reading: The subject must read the words displayed aloud. The statistical analysis was performed using SPSS software.

\section{Results and Discussion}

The obtained scores in the four activities of the LABBEL battery are shown in (Table 1$)$, we find a mean score of $(8 \pm 1.54)$ in auditory lexical decision, as for the visual lexical decision the mean score was $(8.31 \pm 1.76)$, regarding the auditory discrimination mean score was $(8.97 \pm 1.54)$, and finally the mean score of complex words reading was $(8.55 \pm 2.17)$.

The correlation between the reading score and the visual lexical decision score (Table 2) shows that students with reading difficulties do not manage to constitute a mental lexicon, due to the difficulties found in the process of converting graphemes into phonemes. These students cannot read correctly the word 
Table 1. LABBEL battery score means.

\begin{tabular}{ccccc}
\hline & $\begin{array}{c}\text { Complex words } \\
\text { reading }\end{array}$ & $\begin{array}{c}\text { Auditory } \\
\text { discrimination }\end{array}$ & $\begin{array}{c}\text { Auditory lexical } \\
\text { decision }\end{array}$ & $\begin{array}{c}\text { Visual lexical } \\
\text { decision }\end{array}$ \\
\hline Mean & 8.55 & 8.97 & 8.00 & 8.31 \\
SD & 2.17 & 1.40 & 1.54 & 1.76 \\
\hline
\end{tabular}

Table 2. Correlations between reading, discrimination and lexical decision.

\begin{tabular}{ccc}
\hline & $\begin{array}{c}\text { Auditory } \\
\text { discrimination }\end{array}$ & $\begin{array}{c}\text { Visual lexical } \\
\text { decision }\end{array}$ \\
\hline $\begin{array}{c}\text { Complex words } \\
\text { reading }\end{array}$ & $\mathrm{r}=0.30$ & $\mathrm{r}=0.47$ \\
$\mathrm{p}<0.01$ & $\mathrm{p}<0.01$ \\
\hline
\end{tabular}

presented, and consequently do not manage to store it in memory to identify it in a later encounter. The mental lexicon is the set of representations corresponding to the signifying units of the language [15]. There are three types of representations stored separately: orthographic, semantic and phonological representations of words [16]. This conclusion is supported by the existence of a correlation between the visual and auditory lexical decision (Table 3), which confirms a lack of mental lexicon since the student could not manage to recognize the words whether the stimulus was visual or auditory. Stanovich (1986) argues that children who fail to reflect upon speech sounds are unable to perform the grapheme-phoneme conversion operations necessary to access the orthographic stage [17] [18]. This difficulty of vocabulary acquisition hinders the automation of the reading and causes a slowness in this activity.

The correlation between reading and auditory discrimination scores (Table 2) shows that the treatment of the acoustic signal input is not functional in students who have low scores in the discrimination task. The inability to discriminate the words would make the storing of a phonological representation of the word difficult to accomplish. Many studies reported the connection between reading and auditory discrimination [6] [19]. Blau et al. confirmed that letter-speech sound integration, in the auditory cortex, is important in learning to read and that it develops differently in those with reading disorders [20]. Another study aimed to clarify the relationship between auditory processing and reading ability found that performance on auditory processing tasks was correlated with reading and spelling scores. The authors proposed that good readers experience accurate sound representation, which facilitates the encoding of acoustic patterns into phonological representations. The high-quality encoding that occurs in proficient readers' allows for the automatic translation of phonological codes into written language, with little or no effort [21]. El Azmy et al. usuing the auditory discrimination task was able to separate good from weak readers in secondary school pupils [22]. A simple linear regression was calculated to predict reading scores based on the auditory discrimination scores, a significant regression equation was found $(\mathrm{F}=10.147, \mathrm{p}<0.001)$. There is therefore a statistically significant relationship between auditory discrimination and reading. We can 
Table 3. Correlation between auditory and visual lexical decision.

\begin{tabular}{cc}
\hline & Visual lexical decision \\
\hline \multirow{2}{*}{ Auditory lexical decision } & $\mathrm{r}=0.39$ \\
$\mathrm{p}<0.01$ \\
\hline
\end{tabular}

conclude that the auditory discrimination score is a good predictor of the reading score for our sample. These results are consistent with the El Azmy et al findings which showed that auditory discrimination is an indicator of the diagnosis of reading disorders [22]. A remediation program based on the awakening of the necessary discrimination capacities would be beneficial for a good installation of a mental lexicon and the automation of reading, especially that auditory discrimination has been successfully proven as a remediation tool in a sample of Moroccan students [23].

\section{Conclusion}

The objective of this study was to demonstrate the importance of auditory discrimination in the acquisition of mental lexicon and consequently the automation of reading in a sample of 101 students in their fourth year of primary education coming from four different schools in Kenitra (Morocco). After analyzing the results, we were able to emphasize the importance of having good acoustic discrimination capacities for language development. Students who were successful at the auditory discrimination task are more successful at reading. A remediation program based on improving auditory discrimination capacities using the language assessment battery LABBEL could see reading performance improvement in these students.

\section{References}

[1] El Azmy, J. (2015) Etude des troubles de l'apprentissage de la lecture (dyslexie), de l'intelligence non verbale, des processus attentionnels et essai de remédiation à l'aide du labbel chez un échantillon de collégiens du moyen atlas marocain. Thèse de Doctorat, Université Ibn Tofail, Maroc.

[2] Bisaillon, J.M. (2004) L'identification des mots écrits chez des enfants dyslexiques de deuxième et troisième cycle du primaire: Évaluation des effets d'un programme d'intervention en fonction des différents profils de dyslexie. Thèse de Doctorat, Université de Sherbrooke, Québec.

[3] Frith, U. (1985) Beneath the Surface of Developmental Dyslexia. In: Patterson, K.E., Marshall, J.C. and Cotheart, M., Eds., Surface Dyslexia: Cognitive and Neuropsychological Studies of Phonological Reading, Erlbaum, Londres, 301-330.

[4] El Azmy, J., Ahami, A.O.T., Badda, B. and Ahaji, K. (2018) Lien entre la lecture en arabe a voix haute et la conscience phonologique chez des collegiens Marocains de la region de Mrirt, MAROC. European Journal of Education Studies, 4, 239-255.

[5] Gombert, J.E. (1990) Le développement métalinguistique. PUF, Paris.

[6] Gombert, J.E. (2004) Dissociation entre apprentissages linguistiques et développement cognitif: Le cas de l'apprentissage de la lecture chez des trisomiques. Handicap, Revue de sciences humaines et sociales, 101-102, 47-62. 
[7] Marec-Breton, N., Gombert, J.E. and Colé, P. (2005) Traitements morphologiques lors de la reconnaissance des mots écrits chez des apprentis lecteurs. L'Année Psychologique, 105, 9-45. https://doi.org/10.3406/psy.2005.3818

[8] Touhami, M.S. (2015) Les stratégies d'apprentissage de la lecture: Une perspective comparative et évolutive entre l'arabe et le français. Thèse de Doctorat, Université d'Oran 2, Faculté des Langues Étrangères.

[9] Finnegan, S.D. (1979) Auditory Skills and Word-Calling Ability. Academic Therapy, 14, 299-312. https://doi.org/10.1177/105345127901400307

[10] Santos, B., Bagetti, T., Kist, F.R.Z., Mota, H.B. and Keske-Soares, M. (2003) Relação entre o Grau de Severidade do Desvio Fonológico e a Discriminação Auditiva. In: V Congresso Internacional, XI Congresso Brasileiro e I Encontro Cearense de Fonoaudiologia, Fortaleza, 2003. Resumos... Fortaleza: [sn].

[11] Santos, B. (2005) Habilidade de discriminação auditiva em crianças com desvios fonológicos evolutivos. Monografia (especiali-zação em Fonoaudiologia). Universidade Federal de Santa Maria, Santa Maria.

[12] Pereira, L.D. and Ortiz, K.Z. (1997) Desordem do processamento auditivo central e distúrbios da produção fonoarticulatória. In: Lichtig, I. and Carvalho, R.M.M., Eds., Audição: Abordagens atuais, Pró-Fono, 173-186.

[13] Mimouni, Z. and Beland, R. (2009) Language Assessment Battery, Batterie d'évaluation du langage (version arabe). 3 rd Mediterranean Conference of Neuroscience, Alexandria, 13-16 December 2009. https://doi.org/10.3389/conf.neuro.01.2009.16.107

[14] Sadouss, I.C., Ahami, A.O.T., Mouilly, M., faiz, N., Akhrif, I., Chakhtoura, K., Bouzaboul, M., Loukili, A., Zahouani, A., Aboussaleh, Y., Fondevila, J., Sajoux, I., Ferrer, E. and Oranger, V. (2017) Assessment of Language Disorders in Anemic Pupils in Chaouen Northern Region of Morocco. IOSR Journal of Dental and Medical Sciences, 16, 21-26.

[15] Ammar, M. (1997) Les stratégies d'identification de mots écrits en arabe. Thèse de doctorat en sciences de l'éducation (non publiée), Université de Nantes.

[16] Patterson, C.J., Cosgrove, J.M. and O'Brien, R.G. (1980) Nonverbal Indicants of Comprehension and Noncomprehension in Children. Developmental Psychology, 16, 38-48. https://doi.org/10.1037/0012-1649.16.1.38

[17] Stanovich, K.E. (1986) Matthew Effects in Reading: Some Consequences of Individual Differences in the Acquisition of Literacy. Reading Research Quarterly, 21, 360-407. https://doi.org/10.1598/RRQ.21.4.1

[18] Badda, B. (2008) Apprentissage de la lecture, dyslexie phonologique et remédiation par le logiciel Itinéraire Combinatoire chez l'enfant marocain. Thèse de Doctorat en co-tutelle.Université Ibn Tofail (Directeur de thèse: A.O.T. AHAMI Maroc) \& Université de Rennes 2 (Directeur de thèse: J.E. GOMBERT France).

[19] Goswami, U. and Bryant, P.E. (1990) Phonological Skills and Learning to Read. Lawrence Erlbaum, Hillsdale.

[20] Blau, V., Reithler, J., van Atteveldt, N., Seitz, J., Gerretsen, P., Goebel, R. and Blomert, L. (2009) Deviant Processing of Letters and Speech Sounds as Proximate Cause of Reading Failure: A Functional Magnetic Resonance Imaging Study of Dyslexic Children. A Journal of Neurology, 133, 868-879.

[21] Ahissar, M., Protopapas, A., Reid, M. and Merzenich, M.M. (2000) Auditory Processing Parallels Reading Abilities in Adults. PNAS, 97, 6832-6837.

https://doi.org/10.1073/pnas.97.12.6832 
[22] El Azmy, J., Ahami, A. and Badda, B. (2015) Auditory Discrimination as Dyslexia Diagnostic Indicator among Arabic-Speaking Subject. International Journal of Innovation and Applied Studies, 12, 190-196.

[23] Ahami, A., El Azmy, J., Badda, B. and Aboussaleh, Y. (2015) Auditory Discrimination Task as a Technique of Cognitive Remediation of Dyslexia Disorders among Arabic-Speaking Subjects. ANAE, 136-137, 305-310. 